\title{
Is Tocilizumab A Risk Factor for Lower Gastrointestinal Perforations? Isolated Cecal Necrosis: A Rare Case Report
}

\author{
Tocilizumab; Alt Gastrointestinal Sistem Perforasyonları için Bir Risk \\ Faktörü Mü? İzole Çekum Nekrozu: Nadir Bir Olgu Sunumu
}

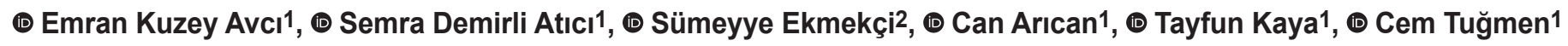 \\ 1 University of Helath Sciences, Tepecik Training and Research Hospital, Clinic of General Surgery, İzmir, Turkey \\ 2University of Helath Sciences, Tepecik Training and Research Hospital, Clinic of Pathology, İzmir, Turkey
}

\section{HIIIIII| ABSTRACT}

Isolated cecal necrosis is a rare seen clinical condition. A 53-year-old woman with a history of rheumatoid arthritis and hypertension presented to the emergency room with complaints of abdominal pain and vomiting that persists for two days. She had been using tocilizumab (TCZ) for the last 5 months. Physical examination was compatible with acute abdomen. Abdomen computerized tomography showed a wall thickness approximately $3 \mathrm{~cm}$ on ascending colon that surrounded with significant inflammation. She was operated with a presumptive diagnosis of acute abdomen. During laparotomy, isolated necrosis with 10x9 cm diameter was observed in the cecum. A right hemicolectomy and ileocolostomy was performed. She was discharged on the $8^{\text {th }}$ postoperative day. Postoperative specimen pathology was showed mucosal necrosis sharply separated from normal mucosal walls. Although the side effect profile of newly used drugs such as TCZ is not clear yet; with larger case reports and series can be contributed.

Keywords: Ischemic colitis, necrosis, tocilizumab

\section{||||||||| ÖZ}

Elli üç yaşında kadın hasta, bilinen romatoid artrit ile hipertansiyon tanıları olup karın ağrısı ve kusma şikayetiyle acil servise başvurdu. Son 5 aydır tocilizumab (TCZ) kullanımı mevcuttu. Fizik muayene akut batın ile uyumlu idi. Yapılan abdomen bilgisayar tomografisinde çıan kolonda 3 cm'lik alanda duvar kalınlık artışı ve çevresinde belirgin enflamasyon mevcuttu. Hasta acil operasyona alındı. Çekumda 6x8 cm'lik alanda nekroz izlendi. Hastaya sağ hemikolektomi ve ileokolostomi uygulandı. Postoperatif 8. günde sorunsuz taburcu edildi. Postoperatif spesimen patolojisinde normal mukozal duvarlardan keskin şekilde ayrılan mukozal nekroz izlendi. TCZ gibi yeni kullanılmaya başlanan ilaçların yan etki profilleri henüz netleşmemekle birlikte olgu takdimleri ile buna katkı sağlanmaktadır.

Anahtar Kelimeler: İskemik kolit, nekroz, tocilizumab

\section{Introduction}

Isolated cecal necrosis (ICN) is a rare and life-threatening condition. Colonic ischemia may be related to hypoperfusion in mesenteric vessels, which is generally encountered in the elderly population. Its incidence is estimated to be 16 cases per 100,000 person-year. ${ }^{1}$ Its diagnosis is difficult due to the lack of specific history, physical examination and imaging findings. It is seen more often in patients with aortoiliac reconstruction, cardiopulmonary bypass, congestive heart failure, atherosclerotic vascular disease, chronic renal failure requiring hemodialysis.

Address for Correspondence/Yazışma Adresi: Emran Kuzey Avcı MD,

University of Helath Sciences, Tepecik Training and Research Hospital, Clinic of General Surgery, İzmir, Turkey

Phone: +90 5354058481 E-mail: emransunaykerim@gmail.com ORCID ID: orcid.org/0000-0002-9221-4959

Received/Geliş Tarihi: 18.10.2019 Accepted/Kabul Tarihi: 05.11.2019

${ }^{\oplus}$ Copyright 2020 by Turkish Society of Colon and Rectal Surgery

Turkish Journal of Colorectal Disease published by Galenos Publishing House. 
In this study, we aimed to present the ICN case that resulted in a right hemicolectomy in a patient having the diagnosis of rheumatoid arthritis (RA) and using tocilizumab (TCZ).

\section{Case Report}

A 53-year-old female patient presented to the emergency room with the complaints of abdominal pain, nausea, vomiting and loss of appetite ongoing for 2 days. She stated that her abdominal pain had increased intensely for the last 12 hours. She had no history of surgical operation except radiotherapy, trauma and laparoscopic cholecystectomy. The body mass index of the patient was 39.9. She had a history of different doses of methylprednisolone, oral/ subcutaneous methotrexate (MTX), and antihypertensive drug use for 16 years due to RA and hypertension. Five months ago, TCZ was started to be $8 \mathrm{mg} / \mathrm{kg} / \mathrm{month}$, along with the use of methylprednisolone $4 \mathrm{mg} / \mathrm{day}$, hydroxychloroquine $200 \mathrm{mg}$ /day, leflunamide $20 \mathrm{mg} /$ day, candesartan cilexetil + hydrochlorothiazide 16 mg-12.5 $\mathrm{mg}$ /day, calcium carbonate + cholecalciferol $600 \mathrm{mg}-400$ IU/day. On physical examination, there was widespread tenderness and rebound in the abdomen, which was evident in the right lower quadrant. In the laboratory parameters, there was no feature other than WBC $10700 \times 10^{3} / \mathrm{uL}$. In IV contrast abdominal computed tomography (CT), the lateral wall of the cecum was very thin, the ascending colon had an increase in wall thickness in the $3 \mathrm{~cm}$ segment and there were changes secondary to inflammation around the cecum. In addition, no signs were found in favor of arterial thrombus or embolism (Figure 1). Free air was not observed in the pneumatosis intestinalis or abdomen. The patient was evaluated as acute abdomen and a laparotomy decision was taken.

During the operation, there was fluid in the abdomen in the form of broth. A necrotic wall lesion of approximately $6 \times 8 \mathrm{~cm}$ was observed at the lateral of the cecum (Figure 2). Right hemicolectomy and side-to-side ileocolostomy were performed to the patient. She was discharged on the $8^{\text {th }}$ postoperative day without any problem.

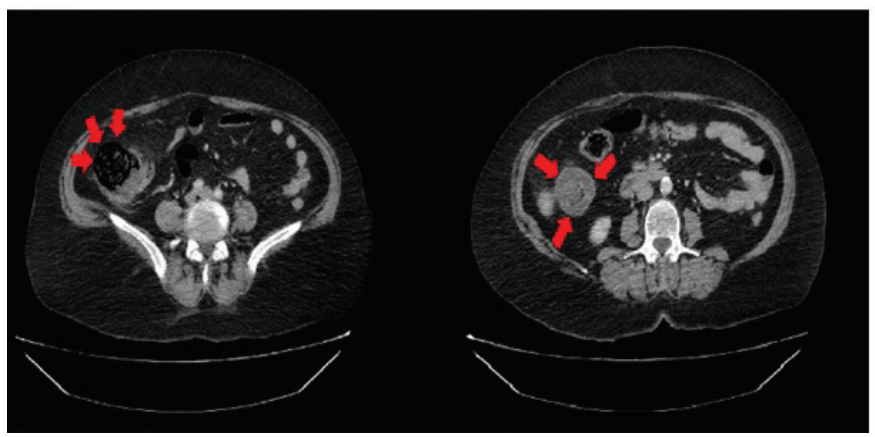

Figure 1. Thinned cecum wall and pericecal contamination
In the pathological examination of the specimen, an intestinal segment, which was sharply separated by normal mucosal tissues, was observed in an area of $10 \times 9 \mathrm{~cm}$ in the macroscopically excised colon segment. Mucosal necrosis, edema, congestion (Figure 3) and active chronic inflammatory granulation tissue extending to the serosa, which microscopically showed a sharp transition with normal mucosa (Figure 4), were observed. No signs of malignancy were seen. Among the specific histopathological findings that would support mesenteric ischemia, which was included in the differential diagnosis of these findings,

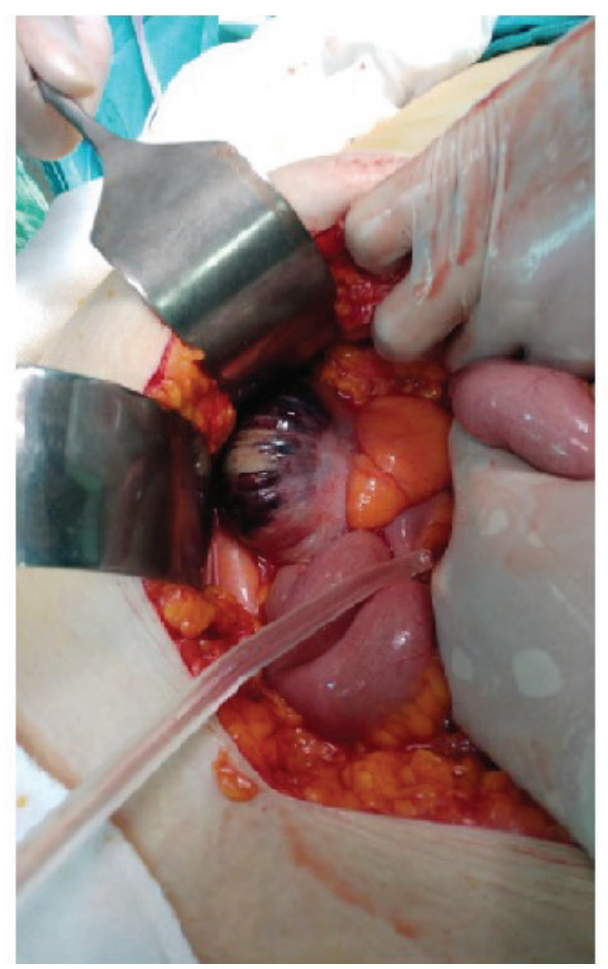

Figure 2. View during operation

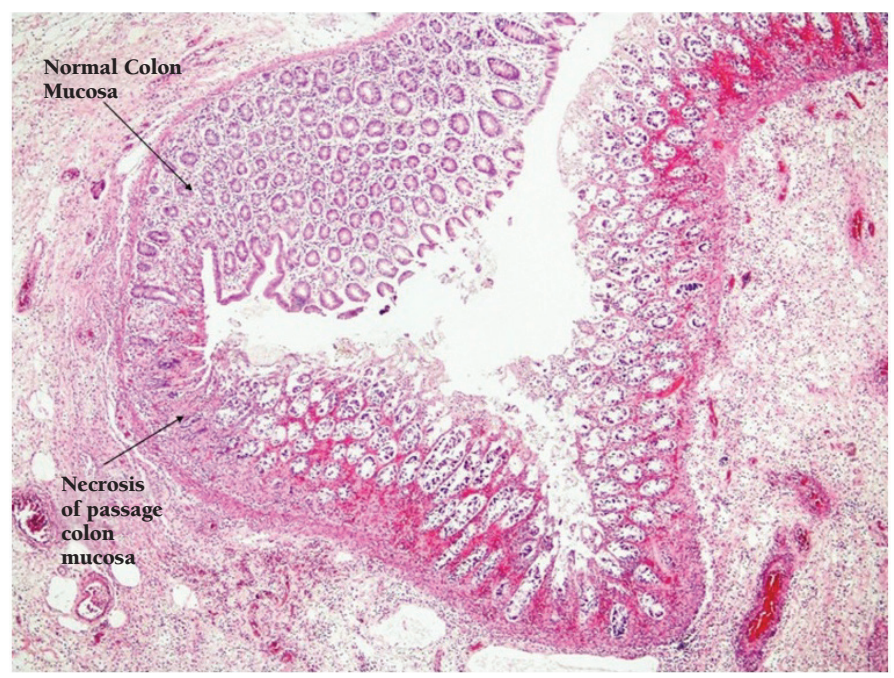

Figure 3. Sharp passage of normal colon mucosa and ischemic bowel segment (H\&E, x40) 
there were no findings such as phlebitis and thrombus in the vascular structures in the mesenteric adipose tissue.

After the operation, the treatment of the patient was replaced by adalimumab, which is the tumor necrosis factor -a monoclonal antibody. Along with other treatments available, she uses adalimumab $760 \mathrm{mg}$ instead of TCZ.

\section{Discussion}

ICN is a rare surgical pathology. In general, it occurs secondary to intestinal ischemia, which develops as a result of the inability to meet the oxygen and nutrients required for cellular metabolism due to a decrease in blood flow. ${ }^{2}$ Due to the richness of colon vascularity, it can be fed from many areas. Its having extensive collateral circulation prevents the development of colonic ischemia. However, splenic flexura and rectosigmoid junction contain the areas of the colon that we call "watershed" areas. ${ }^{3}$ Since collateral blood flow is weaker here, they are especially more prone to ischemia. It is thought that ICN can develop secondary to the pathology in the end branches of the arteries feeding the cecum. The exact cause of isolated ischemia in this area is unknown. Risk factors associated with colonic ischemia are previous abdominal or cardiovascular surgery, atherosclerosis, arrhythmias, chronic obstructive pulmonary disease, hyperhypotension conditions, shock, irritable bowel syndromes, drugs, diabetes mellitus, RA and other rheumatological diseases. ${ }^{2,4}$ Prevalence increases with increasing age and comorbidities. This leads to an increase in the incidence of ischemic colitis as the population ages. ${ }^{4}$ In a retrospective study conducted on 209 patients, an increase in the incidence of ischemic colitis has been shown in people aged 65 years and over. ${ }^{5}$

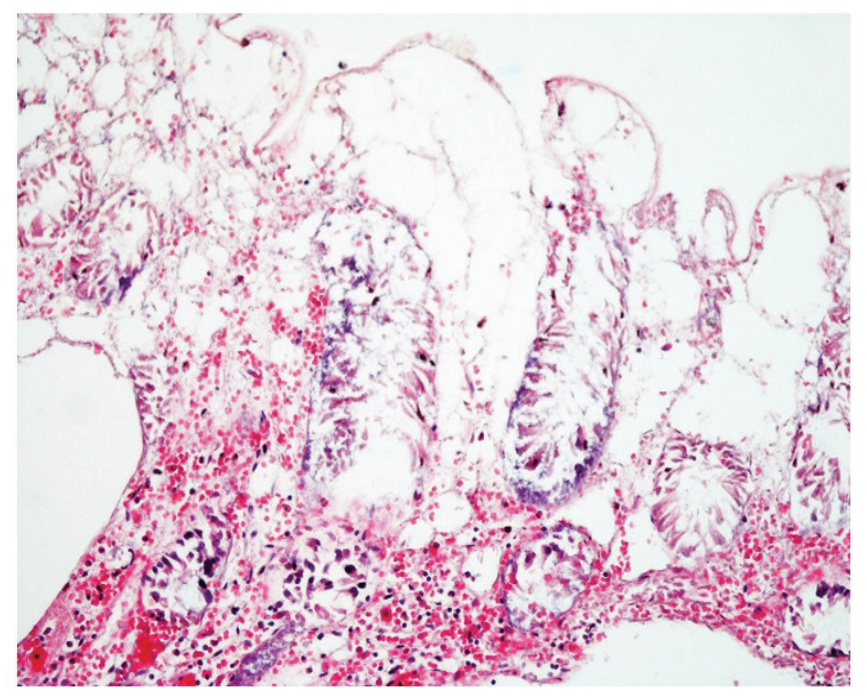

Figure 4. Mucosal necrosis, congestion and edema in the colon (H\&E, $\mathrm{x} 200$ )
Colonic ischemia should be suspected in patients presenting with nonspecific findings such as pain in the lower quadrants of the abdomen, bloody diarrhea, and hematochezia. Having advanced age and additional diseases makes diagnosis difficult. Although there is only localized necrosis at the beginning, if it is complicated (perforation, intra-abdominal abscess, fecal peritonitis), it causes an increase in mortality and morbidity.

Drug research is still ongoing for the treatment of autoimmune diseases and many new drugs are used in treatment. One of them, which is used in the treatment of RA, TCZ, is a monoclonal antibody producing IL-6 receptor blocker. TCZ can be used alone or together with diseasemodifying antirheumatic drugs (DMARDs) in the treatment of RA. There are limited number of studies showing that TCZ increases the risk of perforation of the lower gastrointestinal (GI) system. It has been reported that GI perforations are observed more frequently in patients receiving TCZ therapy as monotherapy or in combination for RA treatment. ${ }^{6,7,8}$ It is known that treatments such as MTX, nonsteroidal anti-inflammatory drugs (NSAIDs) or glucocorticoids, which patients have used or are still using, contribute to the development of GI perforations and increase the risk of perforation. ${ }^{9,10}$ As the effect of TCZ, although the exact mechanism of GI perforations due to IL-6 receptor blockade is not yet understood, it is thought they may be associated with the effects of IL-6 inhibition on vascular endothelial growth factor (VEGF). ${ }^{11}$ VEGF plays an important role in maintaining the integrity of the intestinal mucosa in intestinal damage caused by acute or chronic processes, and it is a targeted cytokines in many cancer treatments as it is highly effective during angiogenesis. ${ }^{12}$ Similar to TCZ, clinical studies have shown that drugs with active substance of bevacizumab, another VEGF inhibitor, are also associated with GI perforations. ${ }^{13}$

Therefore, a decrease in VEGF levels may increase the risk of GI perforation. ${ }^{11}$ Especially in the treatment of elderly RA patients with a history of diverticulitis, the use of these drugs should be paid attention; likewise, the use of TCZ alone in patients with a history of diverticulitis increases the risk of lower GI perforation. ${ }^{10,14}$ In ancient times, GI complications were among the most common causes of death in patients diagnosed with RA. ${ }^{15}$ In colon diseases requiring surgical intervention, increased survival rate was provided with early diagnosis and an appropriate definitive surgery.

Besides medical treatments used, GI perforations in patients with RA suggest that the disease may be secondary to the occurrence of vasculitis or other autoimmune causes. In the presented case, the absence of systemic disease other than HT and the history of TCZ started in the last 6 months due to RA suggested that TCZ might be associated with ICN, 
in other words ischemic colitis. In the literature, a patient diagnosed with pneumotosis due to the use of TCZ and followed non-operatively has also been presented. ${ }^{16}$ The side effect profile of newly used drugs such as TCZ has not been clarified yet, but case reports and series contribute to it.

In conclusion, it should be kept in mind that one of the above mentioned risk factors and one of the complications related to the drugs used in the treatment of these risk factors may be ischemic colitis. Although the relationship between TCZ and intestinal perforation is not yet clear, pathophysiology can be elucidated by studies in this direction. Shortly after the patient's symptoms started, her applying to the emergency room and a quick decision-making for operation enabled the completion of the treatment without any complications associated with the disease.

\section{Ethics}

Informed Consent: Written informed consent was obtained from the patient who participated in this study.

Peer-review: Internally and externally peer reviewed.

\section{Authorship Contributions}

Concept: E.K.A., S.D.A., S.E., C.A., T.K., C.T., Design: E.K.A., S.D.A., S.E., C.A., T.K., C.T., Data Collection or Processing: E.K.A., S.D.A., S.E., C.A., T.K., C.T., Analysis or Interpretation: E.K.A., S.D.A., S.E., C.A., T.K., C.T., Literature Search: E.K.A., S.D.A., S.E., C.A., T.K., C.T., Writing: E.K.A., S.D.A., S.E., C.A., T.K., C.T.

Conflict of Interest: No conflict of interest was declared by the authors.

Financial Disclosure: The authors declared that this study received no financial support.

\section{References}

1. Yadav S, Dave M, Edakkanambeth Varayil J, Harmsen WS, Tremaine WJ, Zinsmeister AR, Sweetser SR, Melton LJ 3rd, Sandborn WJ, Loftus EV Jr. A Population-based Study of Incidence, Risk Factors, Clinical Spectrum, and Outcomes of Ischemic Colitis. Clin Gastroenterol Hepatol 2015;13:731738.el-6; quiz e4l.

2. Brandt LJ, Feuerstadt P, Longstreth GF, Boley SJ; American College of Gastroenterology. ACG clinical guideline: epidemiology, risk factors, patterns of presentation, diagnosis, and management of colon ischemia (CI). Am J Gastroenterol 2015;110:18-44; quiz 45.

3. Gandhi SK, Hanson MM, Vernava AM, Kaminski DL, Longo WE. Ischemic colitis. Dis Colon Rectum 1996;39:88-100.

4. Trotter JM, Hunt L, Peter MB. Ischaemic colitis. BMJ 2016;355:16600.

5. Uchida T, Matsushima M, Orihashi Y, Dekiden-Monma M, Mizukami H, Nakahara F, Nakamura J, Fujisawa M, Koike J, Suzuki T, Mine T. A Casecontrol Study on the Risk Factors for Ischemic Colitis. Tokai J Exp Clin Med 2018;43:111-116.

6. Strangfeld A, Richter A, Siegmund B, Herzer P, Rockwitz K, Demary W, Aringer M, Meißner Y, Zink A, Listing J. Risk for lower intestinal perforations in patients with rheumatoid arthritis treated with tocilizumab in comparison to treatment with other biologic or conventional synthetic DMARDs. Ann Rheum Dis 2017;76:504-510.

7. Xie F, Yun H, Bernatsky S, Curtis JR. Brief Report: Risk of Gastrointestinal Perforation Among Rheumatoid Arthritis Patients Receiving Tofacitinib, Tocilizumab, or Other Biologic Treatments. Arthritis Rheumatol 2016;68:2612-2617.

8. Monemi S, Berber E, Sarsour K, Wang J, Lampl K, Bharucha K, PethoeSchramm A. Incidence of Gastrointestinal Perforations in Patients with Rheumatoid Arthritis Treated with Tocilizumab from Clinical Trial, Postmarketing, and Real-World Data Sources. Rheumatol Ther 2016;3:337-352.

9. Higgins PD, Davis KJ, Laine L. Systematic review: the epidemiology of ischaemic colitis. Aliment Pharmacol Ther 2004;19:729-738.

10. Gout T, Ostör AJ, Nisar MK. Lower gastrointestinal perforation in rheumatoid arthritis patients treated with conventional DMARDs or tocilizumab: A systematic literature review. Clin Rheumatol 2011;30:14711474.

11. Jagpal A, Curtis JR. Gastrointestinal Perforations with Biologics in Patients with Rheumatoid Arthritis: Implications for Clinicians. Drug Saf 2018:41:545-553.

12. Schmidinger $M$. Understanding and managing toxicities of vascular endothelial growth factor (VEGF) inhibitors. EJC Suppl 2013;11:172-191.

13. Hurwitz H, Fehrenbacher L, Novotny W, Cartwright T, Hainsworth J, Heim W, Berlin J, Baron A, Griffing S, Holmgren E, Ferrara N, Fyfe G, Rogers B, Ross R, Kabbinavar F. Bevacizumab plus Irinotecan, Fluorouracil, and Leucovorin for Metastatic Colorectal Cancer. N Engl J Med 2004:350:2335-2342.

14. Curtis JR, Xie F, Chen L, Spettell C, McMahan RM, Fernandes J, Delzell E. The incidence of gastrointestinal perforations among rheumatoid arthritis patients. Arthritis Rheum 2011;63:346-351.

15. Higgins PD, Davis KJ, Laine L. Systematic review: the epidemiology of ischaemic colitis. Aliment Pharmacol Ther 2004;19:729-738.

16. Jacobs B, Jawad A, Fattah Z. Pneumatosis intestinalis and intestinal perforation in a patient receiving tocilizumab. Arch Rheumatol 2018;33:372-375 